\title{
Mapping Paleohydrology of the Ephemeral Kuiseb River, Namibia, from Radar Remote Sensing
}

\author{
Philippe Paillou ${ }^{1, *}$, Sylvia Lopez ${ }^{1}$, Eugene Marais ${ }^{2} \mathbb{D}$ and Klaus Scipal ${ }^{3}$ \\ 1 UMR CNR-5804, Université de Bordeaux, 33615 Pessac, France; sylvia.lopez@u-bordeaux.fr \\ Gobabeb Research and Training Centre, P.O. Box 953, Walvis Bay, Namibia; eugene@gobabebtrc.org \\ 3 European Space Agency, ESRIN, 00044 Frascati, Italy; Klaus.Scipal@esa.int \\ * Correspondence: philippe.paillou@u-bordeaux.fr
}

Received: 30 March 2020; Accepted: 12 May 2020; Published: 19 May 2020

\begin{abstract}
The Kuiseb River is one of the major ephemeral rivers of Western Namibia, setting the northern limit of the Namib Sand Sea and outflowing in the Atlantic Ocean at Walvis Bay. Such ephemeral rivers are of the highest importance for the country since they are related both to recent past climatic conditions and to potential water resources. Using high-resolution radar images from the Japanese ALOS-2 satellite, we mapped for the first time the numerous channels hidden under the surface aeolian sediments: while the non-permanent tributaries of the Kuiseb River appear north of its present-day bed, a wide paleochannel system running westward, assumed by previous studies, could be clearly observed in the interdune valleys in the south. Radar-detected channels were studied during fieldwork in May 2019, which produced both subsurface ground-penetrating radar profiles and high-resolution drone-generated digital elevation models. It allowed us to confirm the existence of the "Paleo-Kuiseb" drainage system, a remnant of the Holocene history of the Kuiseb River, moving northward under the progression of the Namib Sand Sea. Our observations also contribute to the explanation of the young age of the linear dunes at the northern edge of the Namib Sand Sea, which are currently active and are pushing the Kuiseb River course toward the north.
\end{abstract}

Keywords: Kuiseb River; Namib Desert; radar; paleochannels; subsurface

\section{Introduction}

Space-borne synthetic aperture radar (SAR) is an active remote sensing technique allowing us, in very dry soils, to probe the subsurface down to several meters. McCauley et al. [1] were the first to demonstrate SAR's subsurface imaging capabilities for a site located in southern Egypt, where radar images revealed buried and previously unknown paleochannels. Later, using the PALSAR instrument from the Japanese ALOS satellite, we were able to map for the first time a continuous $900 \mathrm{~km}$-long paleodrainage system, named the Kufrah River, in eastern Libya [2]. Several studies have also shown that combining the subsurface imaging capability of SAR with the topographic information provided by digital elevation models (DEM) improves the detection of paleohydrological features, such as river channels and lakes [3-5]. In 2014, the Japanese Space Agency (JAXA) launched its new SAR instrument, PALSAR-2, onboard the ALOS-2 Earth observation satellite [6]. This improved version of PALSAR provides full polarimetric capabilities at L-band $(1.2 \mathrm{GHz})$, associated with a better spatial resolution, from $10 \mathrm{~m}$ down to $3 \mathrm{~m}$. Within the framework of JAXA's fourth ALOS Research Announcement, we obtained the allocation of PALSAR-2 scenes in order to study the potential of low frequency SAR to monitor arid environments. One of the selected study sites was the Namib Desert in Namibia, which presents a rich geological and hydrological context. The Namib Desert was also selected as a test site for a European Space Agency (ESA) airborne radar experiment, to assess the potential of very low frequency SAR (P-band at $435 \mathrm{MHz}$ ) for the ESA Earth Explorer BIOMASS mission [7,8]. 
In cooperation with the Namibian Gobabeb Research and Training Center (GRTC), a research center dedicated to the study of the Namib Desert [9], we started a research project on paleohydrology, focusing on the ephemeral Kuiseb River, with the aim to better understand the past history of the Namib Desert and the dynamics of fossil aquifers in the region. Thanks to the analysis of PALSAR-2 radar images, we clearly mapped, for the first time, numerous buried channels related to the Kuiseb River, close to the Gobabeb Center. We mapped the non-permanent tributaries of the river north of its present-day bed and, for the first time, an ancient and wide drainage system, running westward, in the interdune valleys south of the Kuiseb River. Selected channels of this old drainage system were studied during fieldwork in May 2019, which produced both subsurface ground-penetrating radar profiles and high-resolution drone-generated DEMs. We also locally measured the dielectric constant of surface and subsurface sediments in order to estimate the radar wave penetration depth.

\section{The Kuiseb Ephemeral River}

The Kuiseb River, located in Western Namibia, is an ephemeral river flowing across the Namib Desert, with its outflow in the Atlantic Ocean close to Walvis Bay. Such ephemeral rivers are of the highest importance in Namibia [10] and are among the most hydrologically variable fluvial systems. They are also associated with rich ecosystems which are highly sensitive to hydrological alterations and represent potential large fossil water resources. The Kuiseb River is $560 \mathrm{~km}$ long and drains an area of more than $15,000 \mathrm{~km}^{2}$, cutting through the Great Escarpment and flowing from east to west toward the Atlantic Ocean. It is mainly fed by summer rains which produce river floods originating in the wetter upstream area. Flood records have existed since 1960, providing a unique data set to study the river's dynamics. Analysis of these data, combined with the modeling of flood routing and transmission losses, has shown that most of the recharge of the present-day aquifer is from floods of medium and large magnitude [11].

The Kuiseb River also marks the northern border of the Namib Sand Sea as ephemeral floods wash out the dune sand accumulated from the south (see Figure 1). The main sand transport direction in the Namib Sand Sea is from south to north, with a main sediment source being the Orange River, producing an overall pattern of complex linear dunes aligned broadly north-south [12-15]. It has been proposed that these dunes are relics of a cooler, drier and windier climate during the Last Glacial Maximum, supported by the luminescence dating of linear dunes in many areas [16]. The current scenario is that linear dunes of the Namib Sand Sea, while currently active, should have an older Pleistocene core being at least one million years old [15]. The dynamics of individual linear dunes close to the Kuiseb riverbed were estimated to have an extension rate around $2 \mathrm{~m} / \mathrm{y}$ from south to north and around $0.2 \mathrm{~m} / \mathrm{y}$ from west to east [13]. Bristow et al. [17] have combined ground-penetrating radar and luminescence dating to study a large complex linear dune, located $7 \mathrm{~km}$ southeast of the Gobabeb Center. The so-called Warsaw dune $\left(23.62^{\circ} \mathrm{S} / 15.07^{\circ} \mathrm{E}\right)$ is about $70 \mathrm{~m}$ high and $600 \mathrm{~m}$ wide, decreasing in size toward the Kuiseb River in the north. Its construction included three phases: the oldest part at the base of the western flank of the dune was deposited between 5.7 and $5.2 \mathrm{ka}$, then followed by a hiatus between 5.2 and $2.4 \mathrm{ka}$, probably due to an increase of rainfall and vegetation cover which stabilized the dune. The second phase occurred between 2.4 and $0.14 \mathrm{ka}$, during which the dune built toward the east. The last phase, less than 100 years old, mainly concerns sand accumulation at the dune crest.

Near the Gobabeb Center ( $\left.23.56^{\circ} \mathrm{S} / 15.04^{\circ} \mathrm{E}\right)$, well developed fluvial terraces were observed, which have been classified into four surfaces [18]: upper (H), middle 1 (M1), middle 2 (M2) and lower (L). The younger $\mathrm{L}$ surface is 300 to 600 years old, contains dead tree matter buried by dune sand and was formed during a relatively wet period. Layers of calcrete found on the M1 and M2 surfaces suggest that their forming periods were more humid than now. Using radiocarbon dating, the M1 surface was dated 5 to $6.5 \mathrm{ka}$ and the M2 surface was dated circa $22 \mathrm{ka}$. Gypsum-rich layers observed on the $\mathrm{H}$ surface suggest that the paleoenvironment of the terrace-forming periods involved an increased rainfall in the eastern upstream of the river. 


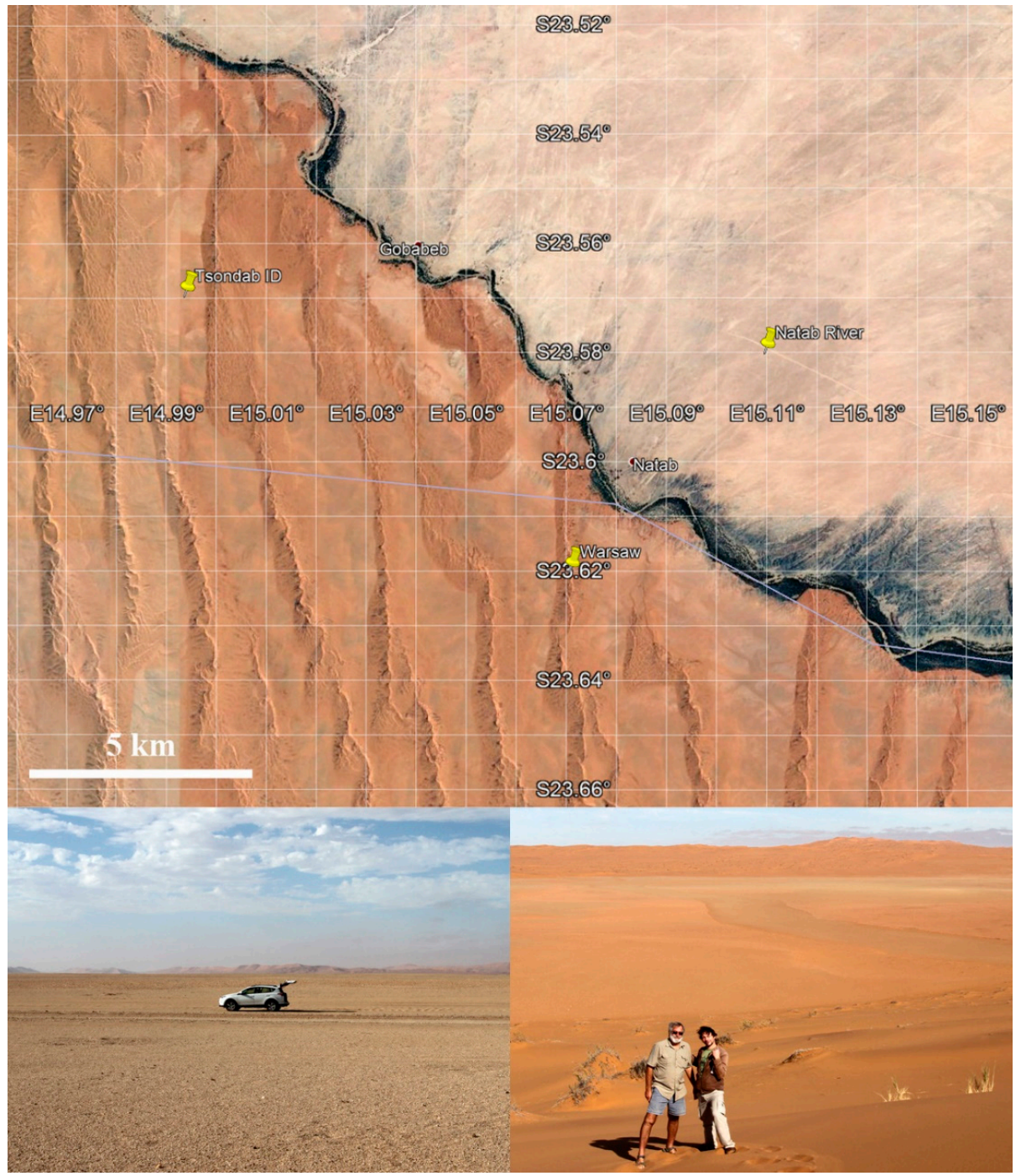

Figure 1. (Top): The Kuiseb River close to the Gobabeb Research Center, marking the limit between the southern dunes of the Namib Sand Sea and the northern desert plain. The three study sites are indicated: Tsondab ID, Natab River and Warsaw dune. (Bottom left): view of the northern rock plain close to Natab River site $\left(23.58^{\circ} \mathrm{S} / 15.11^{\circ} \mathrm{E}\right)$. (Bottom right): view of the interdune valley close to the Tsondab ID site $\left(23.57^{\circ} \mathrm{S} / 14.99^{\circ} \mathrm{E}\right)$.

The Kuiseb River was supposed to be associated with numerous paleochannels, now buried under aeolian sediments, which have incised into the Precambrian basement rocks and the Tertiary deposits of Namib Group sediments [16]. Eckardt et al. [19] made the hypothesis that the lower course of the river gradually shifted northward under the influence of the moving sand dunes from the south, trapping freshwater resources below the present-day sand. The gravel plains north of the Kuiseb River have their own non-permanent drainage network, partly buried under aeolian sediments, either draining into the Kuiseb bed or terminating in small coastal pans. South of the Kuiseb River, the Tsondab sandstone, indicative of a proto-Namib Desert existing some 5 to 20 million years ago, outcrops in the interdune valleys of the Namib Sand Sea (Figure 1). Past ground and aerial geophysical surveys of the area $[20,21]$ identified potential corridors associated with possible paleochannels incising the Tsondab sandstone, which were supposed to be filled with a $50 \mathrm{~m}$-thick layer of calcareous silty fine sand and covered by up to $100 \mathrm{~m}$ of dune sand. Schmidt and Plöthner [22] suggested that the floodwater of the Kuiseb River enters these paleochannels at some locations along the riverbed. Using mixing cell modeling and residence times derived from ${ }^{14} \mathrm{C}$, Klaus et al. [23] have shown that, in addition to 
floodwater, groundwater inflow from the crystalline basement north of the Kuiseb River contributes to the lower Kuiseb aquifer.

\section{Space-Borne Radar Imaging of Paleochannels}

The ALOS-2 Earth observation satellite was launched by the Japanese Space Agency (JAXA) in May 2014. It carries the L-band (1.2 GHz) PALSAR-2 instrument, providing high-resolution and full polarimetric radar images dedicated to cartography, regional observations, disaster monitoring and resource surveys (ALOS-2). We processed two PALSAR-2 scenes, acquired in 2016 and 2017, in ultra-fine $\mathrm{HH}$ polarization stripmap mode with a ground resolution of $3 \mathrm{~m}$, covering the Kuiseb River and centered on the Gobabeb Research Center. Figure 2 shows full resolution extracts for both the Natab River $\left(23.58^{\circ} \mathrm{S} / 15.11^{\circ} \mathrm{E}\right)$ and the Tsondab ID (23.57 $\left.\mathrm{S} / 14.99^{\circ} \mathrm{E}\right)$ study sites. For both sites, the radar penetrated about $2 \mathrm{~m}$ of dry superficial sediments and revealed hidden channels as darker linear features. When reaching a buried channel, the radar wave was absorbed by the filling alluvial sediments, leading to a weak return, while it was backscattered by the rougher bedrock of the channel's banks, leading to a stronger return [24]. Lancaster et al. [25] also previously used RADARSAT and ERS-1 radar images to map relic fluvial patterns in the northern part of the Namib Sand Sea and performed limited field checking of the suspected features. The lower resolution of the radar sensor used $(25 \mathrm{~m})$, together with the lower penetration of C-band $(0.5 \mathrm{~m}$ at $5.6 \mathrm{GHz})$, did not allow them to clearly map the channels. However, they identified areas containing radar-dark lineations and radar-bright calcrete-cemented fluvial surfaces south of the present-day Kuiseb riverbed, extending west.
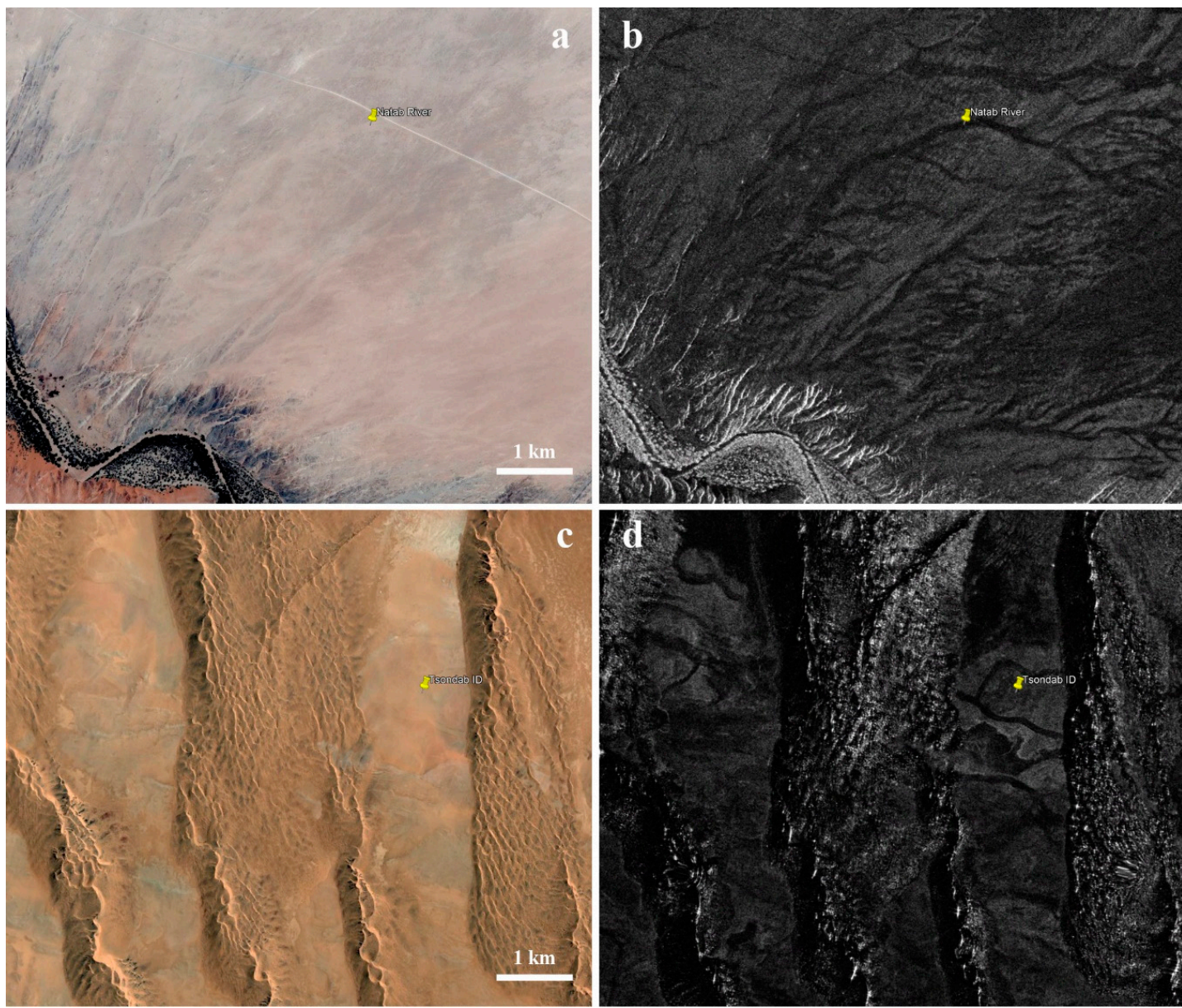

Figure 2. Landsat-7 image (a) and PALSAR-2 radar image (b) of the Natab River study site. Landsat-7 image (c) and PALSAR-2 radar image (d) of the Tsondab ID study site. 
The Kuiseb riverbed marks the limit between the Namib Sand Sea in the south and a flat alluvial plain in the north. In the northern gravel plains (Figure 2a,b), high-resolution PALSAR-2 images clearly show a dense tributary network draining into the present-day Kuiseb riverbed, in particular close to the Natab area, which is the apex of a non-permanent tributary contributing to the Kuiseb aquifer [23]. In the southern Namib Sand Sea (Figure 2c,d), PALSAR-2 data reveal, for the first time, single channels in the interdune valleys between the linear dunes. These paleochannels clearly correspond to the ones previously assumed by Sengpiel and Siemon [21] and Lancaster et al. [25]. Figure 3 shows a larger view of the Gobabeb region, with radar-detected channels. We clearly see two distinct hydrological systems, i.e., a northern network of non-permanent tributaries and a southern corridor of paleochannels. The northern system incises the gravel plain and originates from the foothills of the escarpment, crossing the ancient gravel plain with a thin Tertiary cover [19]. All detected channels connect to the Kuiseb present-day riverbed and probably feed its aquifer. The southern system can be followed from one interdune valley to the next between the linear dunes of the Namib Sand Sea and is oriented from southeast to northwest, heading toward the Atlantic coast. There is no clear main channel but rather remains of several parallel-oriented paleochannels, spreading over an $8 \mathrm{~km}$-wide corridor. They are very likely to be the remaining tracks of the Kuiseb River course, which gradually shifted northward under the influence of moving sand dunes, as proposed by Eckardt et al. [19].

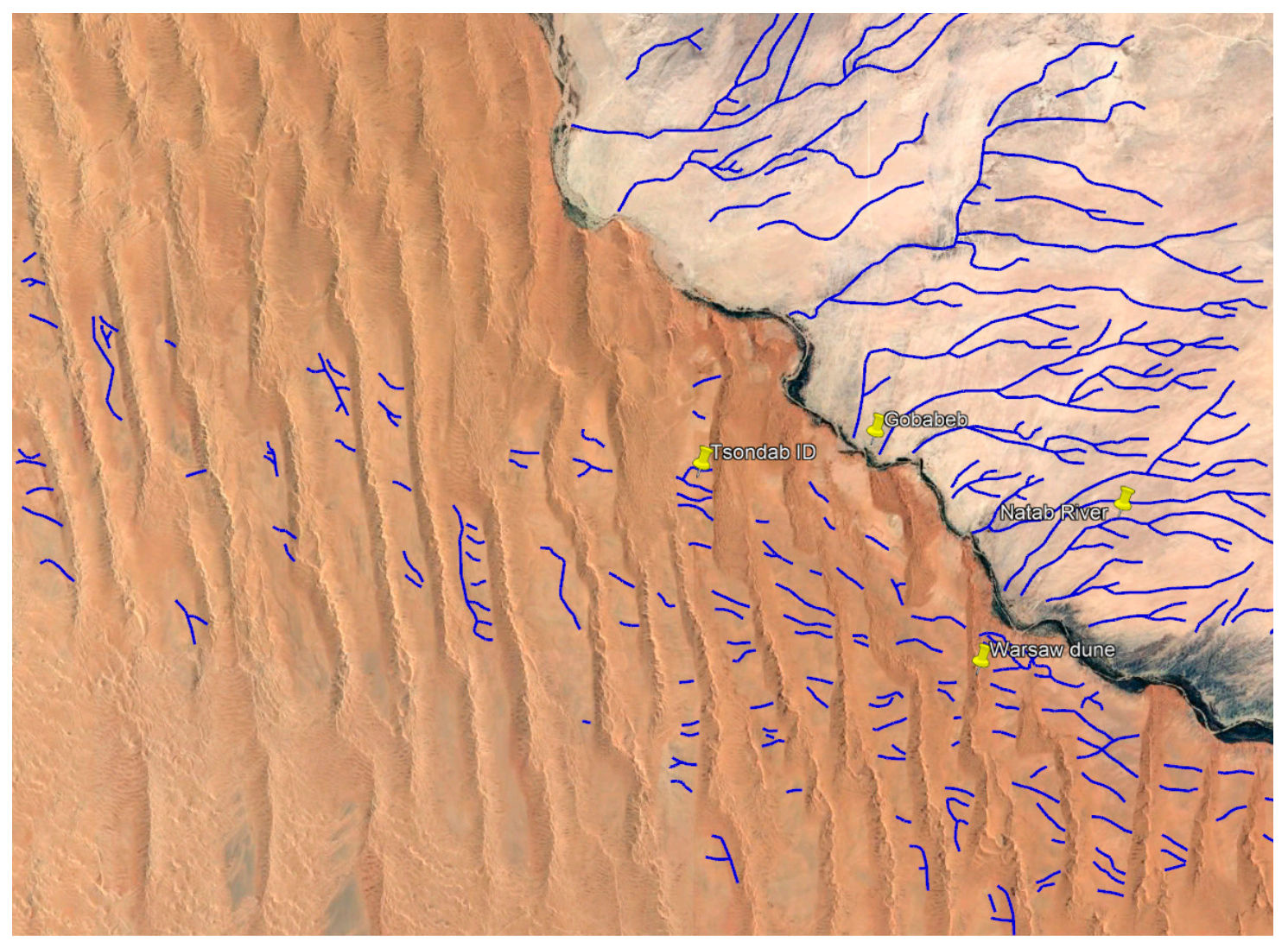

Figure 3. Cont. 


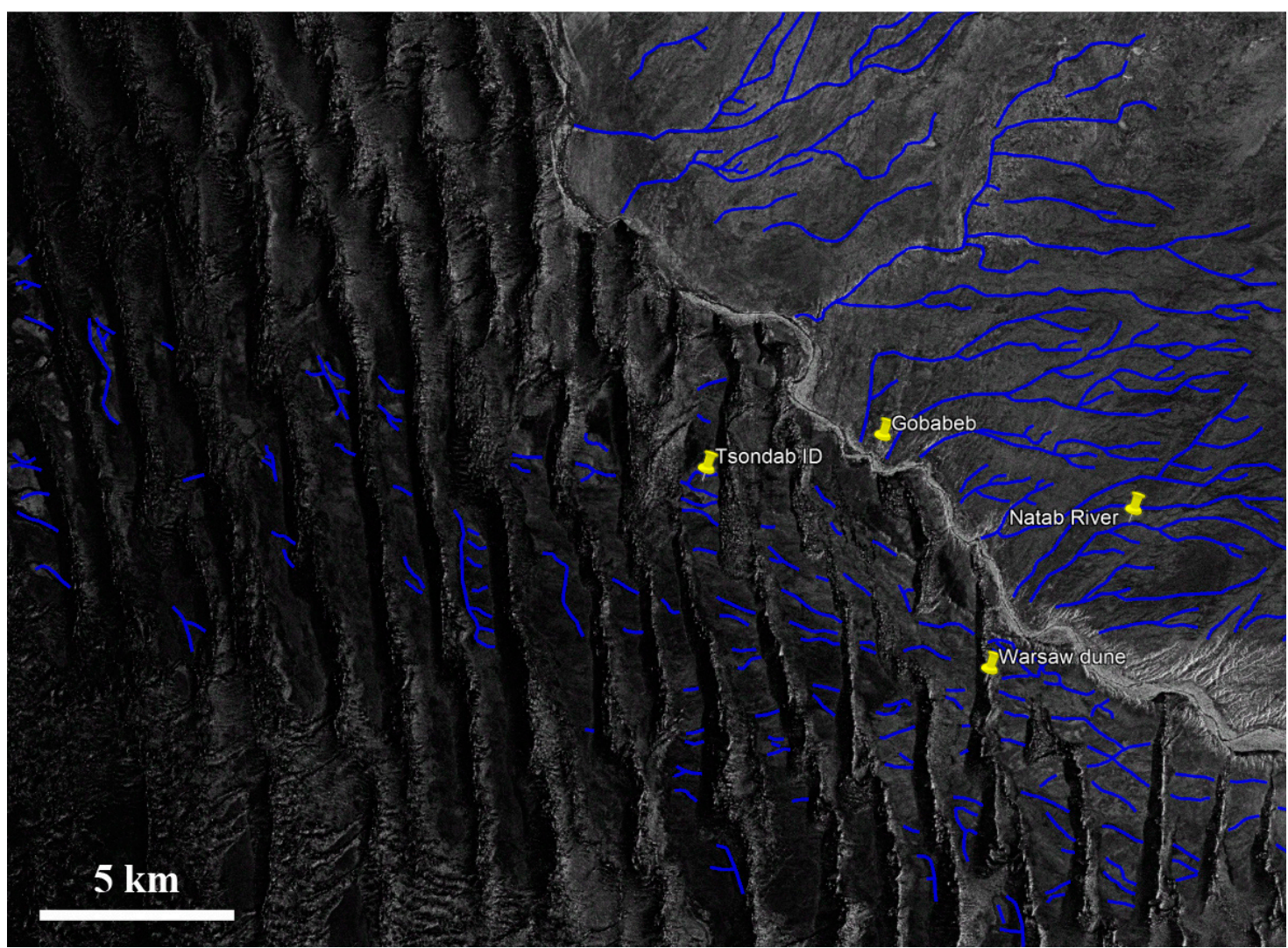

Figure 3. (Top): Landsat image of the Kuiseb River area with radar-detected channels indicated in blue. (Bottom): Corresponding PALSAR-2 radar image.

\section{Field Work}

During May 2019, we conducted experiments in the field in order to characterize selected channels observed in the PALSAR-2 images: we measured the dielectric constant of surface and subsurface sediments in order to estimate the radar wave penetration, image the subsurface channel structures using a ground-penetrating radar (GPR) and produce high-resolution DEMs from drone imaging.

Using a vector network analyzer and a dielectric probe, we measured the complex dielectric constant, at a frequency of $1.2 \mathrm{GHz}$ (L-band), of various surface and subsurface sediment samples at the Natab River and Tsondab ID sites. From these measurements, we computed the loss tangent and skin depth, which weres lower estimates for the radar penetration depth at L-band (see Table 1).

Table 1. Dielectric constant (real part $\varepsilon^{\prime}$ and imaginary part $\varepsilon^{\prime \prime}$ ), loss tangent and skin depth at $1.2 \mathrm{GHz}$ for surface and subsurface sediments at Tsondab and Natab study sites.

\begin{tabular}{ccccc}
\hline Sample & $\varepsilon^{\prime}$ & $\varepsilon^{\prime \prime}$ & $\tan \delta\left(\times \mathbf{1 0}^{-\mathbf{2}}\right)$ & $\mathbf{d p}(\mathbf{m})$ \\
\hline Tsondab Dune & 2.80 & 0.03 & 1.0 & 2.2 \\
Tsondab Surf & 3.17 & 0.07 & 2.2 & 1.0 \\
Channel Surf & 3.22 & 0.08 & 2.4 & 0.9 \\
Channel Sub & 2.76 & 0.11 & 4.0 & 0.6 \\
Natab Dust & 3.04 & 0.08 & 2.7 & 0.8 \\
Natab Surf & 3.05 & 0.07 & 2.3 & 1.0 \\
Natab Sub & 3.53 & 0.31 & 8.8 & 0.2 \\
\hline
\end{tabular}

Figure 4 shows pictures of the places where the dielectric constant measurements were performed. For the Natab River site, we characterized the electric properties of the surface fine dust, the surface mix of dust and small gravels (see Figure 4a) and the subsurface calcrete observed in a buried channel 
(see Figure 4b), respectively referenced as "Natab Dust", "Natab Surf" and "Natab Sub" in Table 1. For the Tsondab ID site, we characterized the electric properties of the surface mix of dust and small gravels on the bank of a paleochannel (see Figure 4c), referenced as "Tsondab Surf" in Table 1. We also characterized the surface mix of dust and calcrete and the subsurface calcrete over a paleochannel running across the interdune valley (see Figure 4d), referenced as "Channel Surf" and "Channel Sub" in Table 1. Finally, we measured the dielectric constant of silicate sand of a close-by linear dune, referenced as "Tsondab Dune" in Table 1. We can observe that the radar penetration depth at L-band, for which the skin depth in Table 1 is a lower estimate, was around $1 \mathrm{~m}$ for surface sediments and lower than a meter when considering subsurface channel material. The higher penetration depth, more than $2 \mathrm{~m}$ at L-band, was measured for the sand constituting the linear dunes.
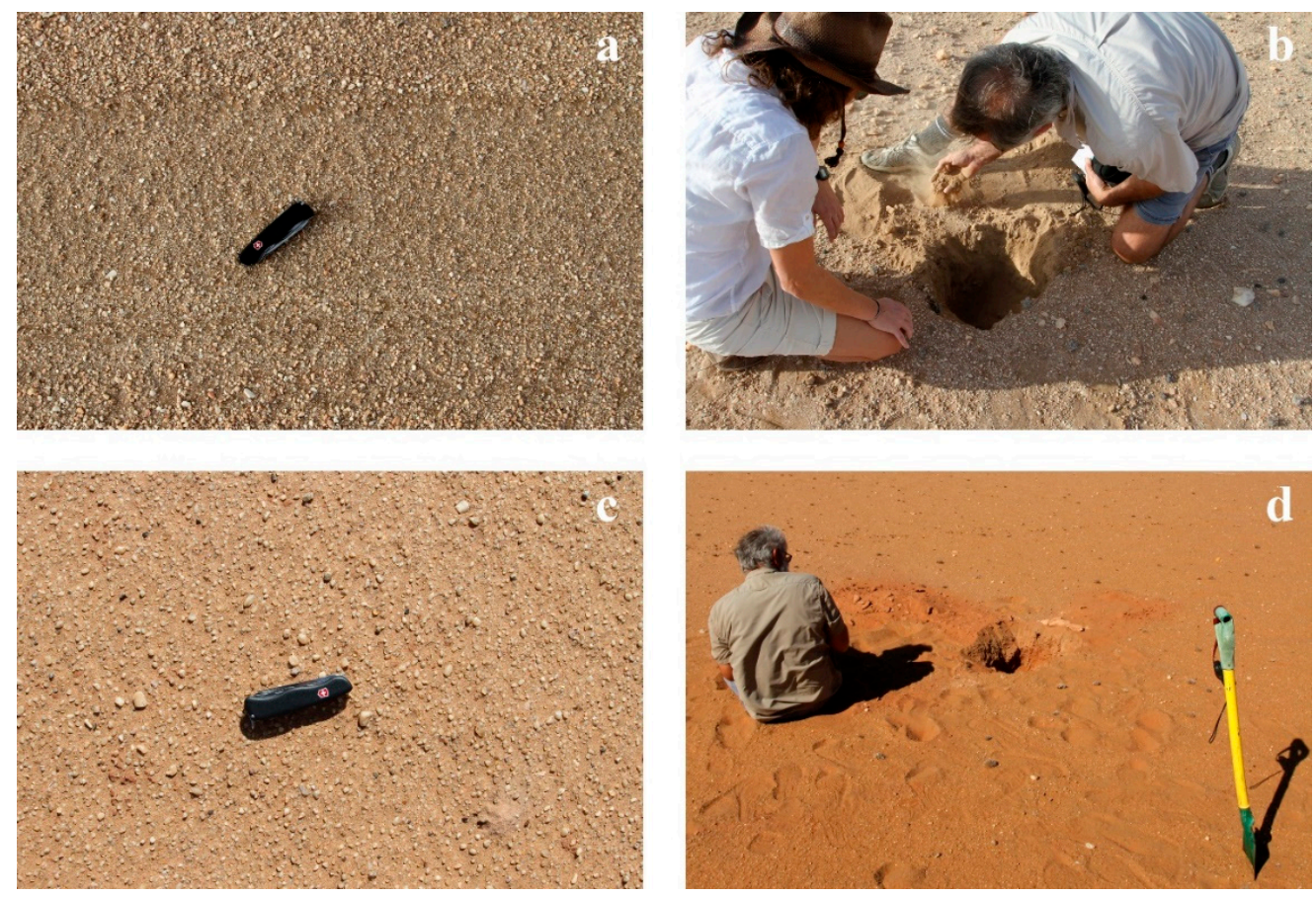

Figure 4. Pictures of the places where the dielectric constant measurements were performed at both Natab River (a,b) and Tsondab ID sites (c, d).

At the Natab River test site, we performed two 200 m-long GPR acquisitions across a non-permanent tributary of the Kuiseb River, coming from the northern plain and connecting the present-day Kuiseb River at the so-called Natab place. It is hard to observe any hydrological features in the very flat gravel plain (see Figure 1 bottom left), but the ground-penetrating radar reveals a three-layers system: a thin $(20 \mathrm{~cm}$ ) layer of fine aeolian dust is covering a 2 to $3 \mathrm{~m}$-thick layer of coarser deposits (see $900 \mathrm{MHz}$ GN1 profile in Figure 5) lying on the sandstone bedrock (see $400 \mathrm{MHz}$ GN1 profile in Figure 5). The 3 m-deep sandstone horizon produces a strong contrast in $400 \mathrm{MHz}$ GPR profiles. The Natab tributary does not clearly appear in the GPR profiles: it only produced a slightly more homogeneous response, likely due to a finer fluvial sediment filling. Nevertheless, the high-resolution DEM generated by the photogrammetric processing of drone acquisitions reveals a slight depression, of less than a meter, at the tributary location (see Figure 5 bottom left). 


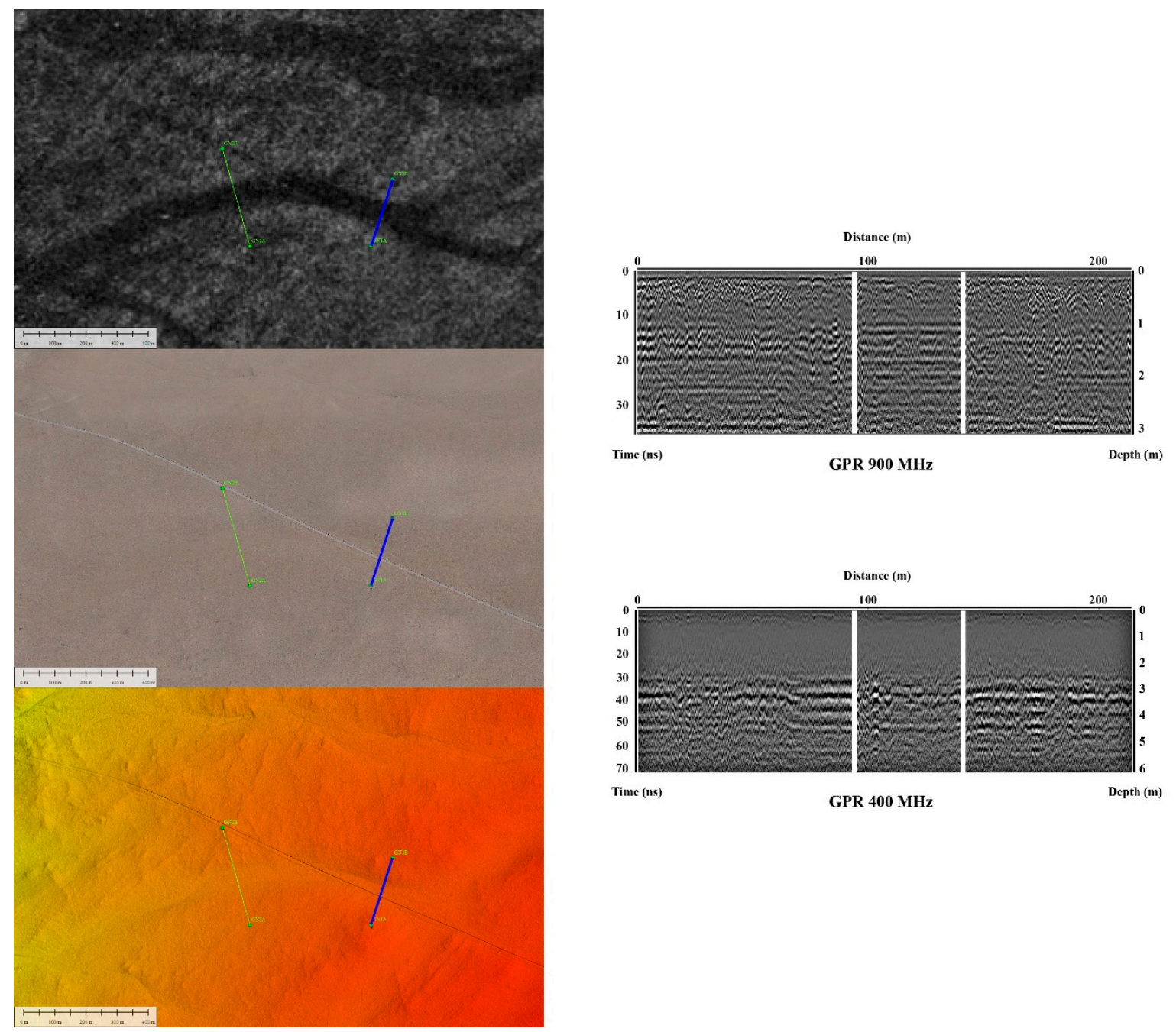

Figure 5. (Left): view of the Natab River test site with GPR profiles GN1 and GN2 (PALSAR-2 top, drone-generated mosaic middle, drone-generated DEM bottom). (Right): GN1 ground-penetrating profile acquired at $900 \mathrm{MHz}$ (top) and $400 \mathrm{MHz}$ (bottom). Depth scale was computed using a dielectric constant $\varepsilon=3$; the buried channel is located between white vertical lines.

At the Tsondab ID site, we acquired six GPR profiles, $100 \mathrm{~m}$ - to $250 \mathrm{~m}$-long, at both 400 and $900 \mathrm{MHz}$ frequencies, across the southern branch of a paleochannel which clearly appears in the PALSAR-2 image (see Figure 6 top left). The drone-generated DEM (see Figure 6 bottom left) shows a clear and sharp depression of less than one meter for the southern channel, while the northern channel does not show any topographic signature. As for the Natab River site, the ground-penetrating radar reveals a three-layers system: a thin $(20 \mathrm{~cm})$ layer of fine aeolian dust is covering a 2 to $3 \mathrm{~m}$-thick layer of coarser deposits (see $900 \mathrm{MHz}$ GT2 profile in Figure 6) lying on the sandstone bedrock (see $400 \mathrm{MHz}$ GT2 profile in Figure 6). Again, the southern paleochannel does not clearly appear in GPR profiles, only producing a slightly more homogeneous response. We were nevertheless able to identify two main subsurface horizons (see arrows 1 and 2 in Figure 6): a shallow and younger one, about one meter deep, and a deeper and then older one at the interface between the superficial deposits and the sandstone bedrock. The shallow horizon was observed in all GPR profiles along the southern channel, which is very likely to be the remnant of the last active channel bed. 


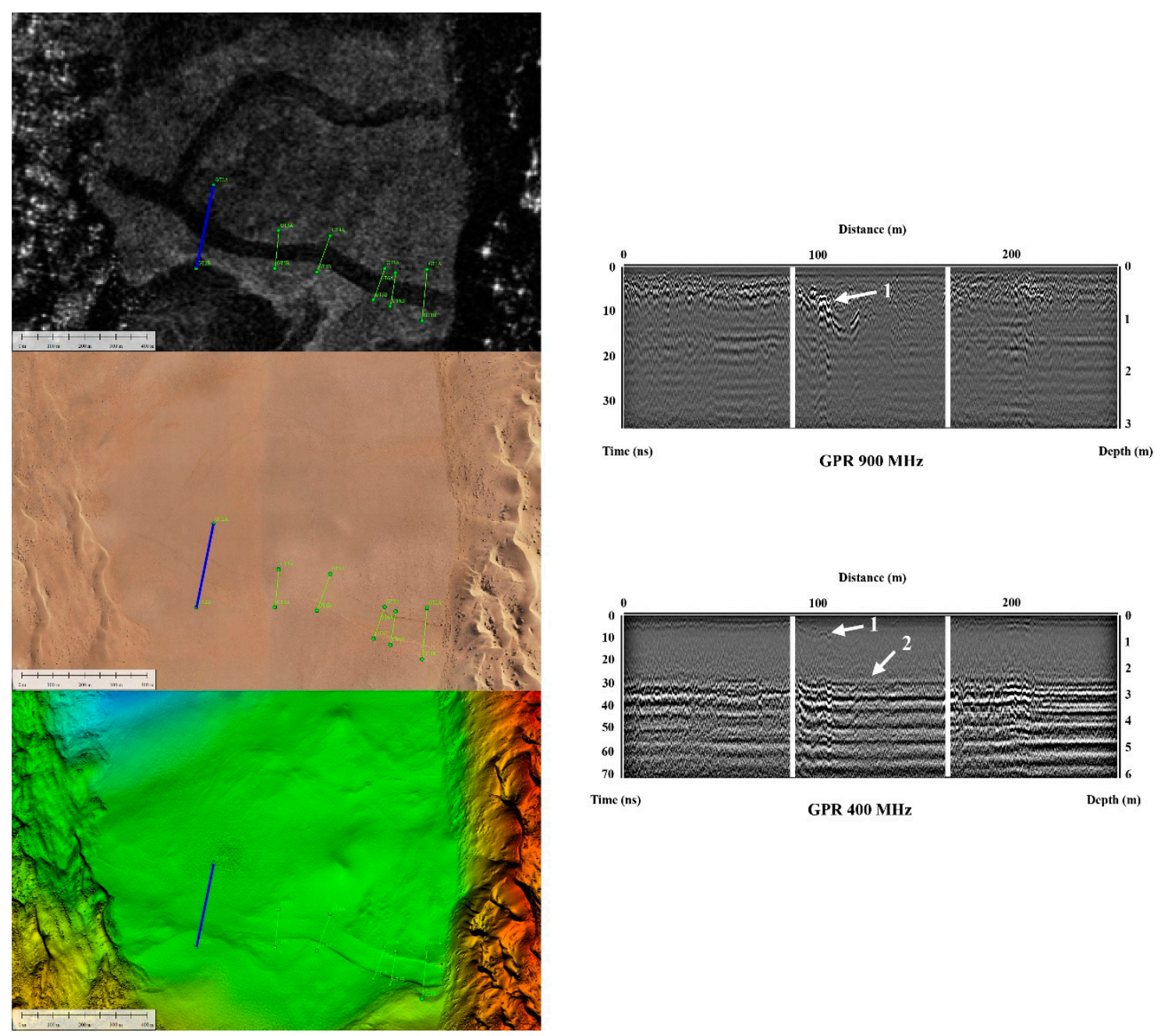

Figure 6. (Left): view of the Tsondab ID test site with GPR profiles GT1 to GT6 (PALSAR-2 top, drone-generated mosaic middle, drone-generated DEM bottom). (Right): GT2 ground-penetrating profile acquired at $900 \mathrm{MHz}$ (top) and $400 \mathrm{MHz}$ (bottom). Depth scale was computed using a dielectric constant $\varepsilon=3$; the paleochannel is located between white lines. Two main horizons are indicated by white arrows 1 and 2 .

At the Warsaw dune, high-resolution images acquired by a drone show surface signatures (change in surface sediment color) which correlate to the radar-detected subsurface channels of the PALSAR-2 sensor (see Figure 7 top). We also acquired there several ground-penetrating radar profiles which confirm the richness of the dune internal structure previously observed by Bristow et al. [17] and the high radar penetration depth in dunes (more than $8 \mathrm{~m}$ ) at a low frequency (see Figure 7 bottom). 

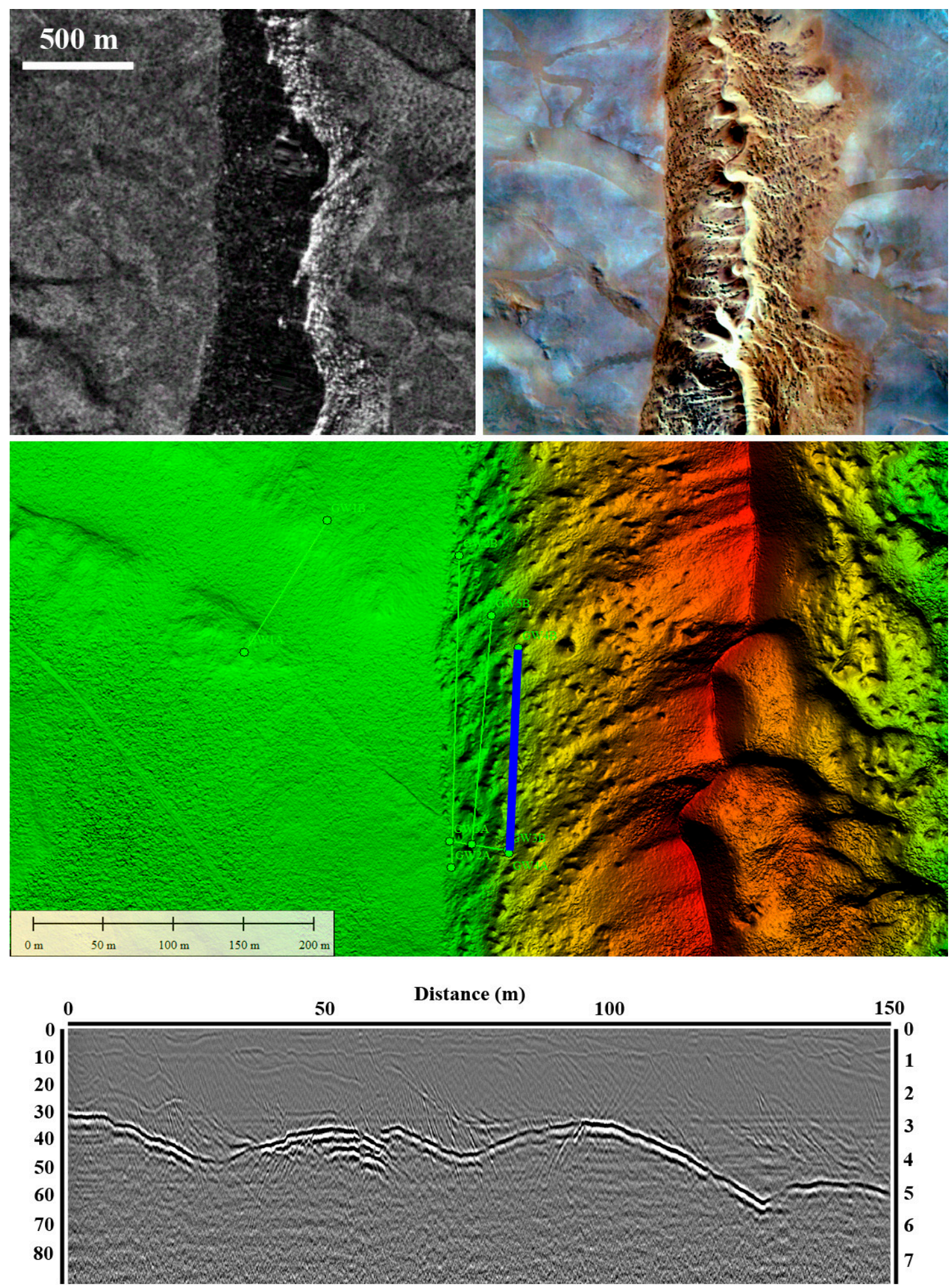

Time (ns)

GPR (400 MHz)

Depth (m)

Figure 7. (Top): PALSAR-2 image of the northern part of the Warsaw dune (left) and drone-generated mosaic of the same area, with image contrast enhanced (right). Middle: Drone-generated DEM of the central part of the Warsaw dune, with GPR profiles location. (Bottom): GW5 ground-penetrating profile acquired at $400 \mathrm{MHz}$ (depth scale was computed using a dielectric constant $\varepsilon=3$ ), showing the subsurface paleochannel under $5 \mathrm{~m}$ of dune's sand. 


\section{Conclusions}

Using the subsurface imaging capabilities of high-resolution space-borne radar, we mapped, for the first time, numerous paleochannels spreading in an $8 \mathrm{~km}$-wide corridor south of the present-day Kuiseb riverbed (see Figure 8), named hereafter "Paleo-Kuiseb". This result confirms previous hypotheses and partial observations of such structures as the remains of former courses of the Kuiseb River $[19,21,25]$ which shifted northward under the influence of the moving dunes of the Namib Sand Sea.



Figure 8. Location of Warsaw dune, present-day Kuiseb riverbed (cyan) and Paleo-Kuiseb system (dark blue), spreading over $8 \mathrm{~km}$ in south-north direction. Dark arrows indicate the main migration direction of Namib sand dunes.

As the Warsaw dune is located in this former fluvial plain (see Figure 8), our observations help explain its younger than expected age (around 5 ka for its oldest core [17]), while the Namib Sand Sea's age is in excess of $1 \mathrm{Ma}$ [15]). The Warsaw dune could not have existed when the Kuiseb riverbed was south of its present-day course and started forming only 5 kyrs ago when the Kuiseb River reached its northern limit. Considering the $8 \mathrm{~km}$ mean width of the Paleo-Kuiseb corridor and making the simplistic hypothesis that all linear dunes in that area started forming $5 \mathrm{kyrs}$ ago, this leads to an average linear migration rate of $1.6 \mathrm{~m} / \mathrm{y}$ from south to north. This value is in good agreement with previous estimates [14,17].

The fact that the Paleo-Kuiseb area is moving gradually further and further away from the present-day Kuiseb riverbed when going westward (see Figure 8) indicates that the linear dune progression is faster and more efficient on the western side of the Namib Sand Sea, and/or a westerly migration component should be considered [17], confirming that the dynamics of the Namib Sand Sea are spatially variable from east to west [13]. 
In all ground-penetrating profiles acquired over a paleochannel located at the Tsondab ID site, we observed a shallow (1 $\mathrm{m}$ deep) and well-marked horizon which is likely to correspond to a stabilized channel bed formed in the recent past, when the Paleo-Kuiseb was flowing water in a quasi-permanent regime over a lasting period: this could correspond to the 5.2 to 2.4 ka wetter climate hiatus proposed by Bristow et al. [17] and to the 5 to 6.5 kyrs old M1 terrace observed close to the Gobabeb Center by Yamagata and Mizuno [18].

The Paleo-Kuiseb area should be deeper investigated in the future: it is a key area in understanding the ongoing dynamics of the northern border of the Namib Sand Sea. It is also potentially a place where archaeological artefacts could be looked for since humans occupied the Namib Sand Sea area intermittently during the Late Pleistocene and Holocene [26]. Finally, the Paleo-Kuiseb channels are likely to still trap fresh and shallow water resources below the present-day dune sands, which could be used for the development of future agricultural activities.

Author Contributions: P.P. was in charge of project management, SAR and GPR data acquisition and processing, data interpretation and analysis, and paper writing. S.L. performed drone acquisitions and data processing, DEM generation and all data integration in GIS. E.M. contributed to field work supervision, defined the geolocical and hydrological context of the study, and participated to data interpretation. K.S. was responsible for ESA contract definition and supervision. All authors have read and agreed to the published version of the manuscript.

Funding: Fieldwork in Namibia was funded by ESA contract no 4000124311/18/NL/CT.

Acknowledgments: We are grateful to JAXA for providing PALSAR-2 images in the framework of the RA4 project \#1026. We also thank ESA for fieldwork support within the BIOMASS DesertSAR project, and the National Commission on Research Science \& Technology of Namibia for the approval of our research permit. We deeply thank Gillian Maggs-Kölling, director of the Gobabeb Research \& Training Center, for her help and continuous support, Charles Bristow for providing samples of the Warsaw sand dune, and Troy Sternberg together with an anonymous reviewer for their advices to improve earlier versions of this paper.

Conflicts of Interest: The authors declare no conflict of interest.

\section{References}

1. McCauley, J.; Schaber, G.G.F.; Breed, C.S.; Grolier, M.J.; Haynes, C.V.; Issawi, B.; Elachi, C.; Blom, R. Subsurface valleys and geoarchaeology of the eastern Sahara revealed by Shuttle Radar. Science 1982, 218, 1004-1020. [CrossRef] [PubMed]

2. Paillou, P.; Schuster, M.; Tooth, S.; Farr, T.; Rosenqvist, A.; Lopez, S.; Malézieux, J.-M. Mapping of a major paleodrainage system in Eastern Libya using orbital imaging Radar: The Kufrah River. Earth Planet. Sci. Lett. 2009, 277, 327-333. [CrossRef]

3. Paillou, P.; Tooth, S.; Lopez, S. The Kufrah Paleodrainage System in Libya: A Past Connection to the Mediterranean Sea? C. R. Geosci. 2012, 344, 406-414. [CrossRef]

4. Robinson, C.; Werwer, A.A.; El-Baz, F.; El-Shazly, M.; Fritch, T.; Kusky, T. The Nubian aquifer in Southwest Egypt. Hydrogeol. J. 2006, 15, 33-45. [CrossRef]

5. Sternberg, T.; Paillou, P. Mapping potential shallow groundwater in the Gobi using remote sensing: Lake Ulaan Nuur. J. Arid Environ. 2015, 118, 21-27. [CrossRef]

6. ALOS-2. Available online: https://www.eorc.jaxa.jp/ALOS-2/en/about/palsar2.htm (accessed on 16 May 2020).

7. Le Toan, T.; Quegan, S.; Davidson, M.; Baltzer, H.; Paillou, P.; Papathanassiou, K.; Plummer, S.; Rocca, F.; Saatchi, S.; Shugart, H.; et al. The BIOMASS mission: Mapping global forest biomass to better understand the terrestrial carbon cycle. Remote Sens. Environ. 2011, 115, 2850-2860. [CrossRef]

8. Quegan, S.; le Toan, T.; Chave, J.; Dall, J.; Exbrayat, J.-F.; D'Alessandro, M.M.; Paillou, P.; Papathanassiou, K.; Rocca, F.; Saatchi, S.; et al. The European Space Agency BIOMASS mission: Measuring forest above-ground biomass from space. Remote Sens. Environ. 2019, 227, 44-60. [CrossRef]

9. Henschel, J.R.; Lancaster, N. Gobabeb—50 years of Namib Desert research. J. Arid Environ. 2013, 93, 1-6. [CrossRef]

10. Jacobson, P.J.; Jacobson, K.M. Hydrologic controls of physical and ecological processes in Namib Desert ephemeral rivers: Implications for conservation and management. J. Arid Environ. 2013, 93, 80-93. [CrossRef] 
11. Morin, E.; Grodek, T.; Dahan, O.; Benito, G.; Kulls, C.; Jacoby, Y.; van Langenhove, G.; Seely, M.; Enzel, Y. Flood routing and alluvial aquifer recharge along the ephemeral arid Kuiseb River, Namibia. J. Hydrol. 2009, 368, 262-275. [CrossRef]

12. Lancaster, N. The Namib Sand Sea: Dune Forms, Processes and Sediments; Balkema: Rotterdam, The Netherlands, 1989.

13. Livingstone, I. Aeolian geomorphology of the Namib Sand Sea. J. Arid. Environ. 2013, 93, 30-39. [CrossRef]

14. Stone, A.E.C. Age and dynamics of the Namib Sand Sea: A review of chronological evidence and possible landscape development models. J. Afr. Earth Sci. 2013, 82, 70-87. [CrossRef]

15. Vermeesch, P.; Fenton, C.R.; Kober, F.; Briggs, G.F.S.; Bristow, C.S.; Xu, S. Sand residence times of one million years in the Namib Sand Sea from cosmogenic nuclides. Nat. Geosci. 2010, 3, 862-865. [CrossRef]

16. Lancaster, N. Low-latitude dune fields. In Encyclopedia of Quaternary Science; Elias, S.A., Ed.; Elsevier: Amsterdam, The Netherlands, 2007; pp. 626-642.

17. Bristow, C.S.; Duller, G.A.T.; Lancaster, N. Age and dynamics of linear dunes in the Namib Desert. Geology 2007, 35, 555-558. [CrossRef]

18. Yamagata, K.; Mizuno, K. Landform Development along the Middle Course of the Kuiseb River in the Namib Desert, Namibia. Afr. Study Monogr. 2005, 30, 15-25.

19. Eckardt, F.D.; Livingstone, I.; Seely, M.; von Holdt, J. The Surface Geology and Geomorphology around Gobabeb, Namib Desert, Namibia. Sweedish Soc. Anthropol. Geogr. 2013, 95, 271-284. [CrossRef]

20. BGR (Bundesanstalt für Geowissenschaften und Rohstoffe). German-Namibian Groundwater Exploration Project-Summary Report; BGR: Bonn, Germany, 2000; p. 76.

21. Sengpiel, K.P.; Siemon, B. Hubschrauberelektromagnetik zur Grundwasserkundung in der Namib-Wüste, Namibia. Z. Angew. Geol. 1997, 43, 130-136.

22. Schmidt, G.; Plöthner, D. Abschätzung der Grundwasservorrate im Fluss- und Dünengebiet des Unteren Kuiseb, Namibia. Z. Angew. Geol. 1999, 45, 124-137.

23. Klaus, J.; Kulls, C.; Dahan, O. Evaluating the recharge mechanism of the Lower Kuiseb Dune area using mixing cell modeling and residence time data. J. Hydrol. 2008, 358, 304-316. [CrossRef]

24. Paillou, P. Mapping palaeohydrography in deserts: Contribution from space-borne imaging radar. Water 2017, 9, 194. [CrossRef]

25. Lancaster, N.; Schaber, G.G.; Teller, J.T. Orbital radar studies of paleodrainages in the Central Namib Desert. Remote Sens. Environ. 2000, 71, 216-225. [CrossRef]

26. Shackley, M.L. Paleolithic archaeology of the Central Namib Desert: A preliminary survey of chronology, typology and site location. In Cimbebasia Memoir 6; Windhoek State Museum: Windhoek, Namibia, 1985; p. 84 .

(C) 2020 by the authors. Licensee MDPI, Basel, Switzerland. This article is an open access article distributed under the terms and conditions of the Creative Commons Attribution (CC BY) license (http://creativecommons.org/licenses/by/4.0/). 